\title{
Brevundimonas vancanneytii sp. nov., isolated from blood of a patient with endocarditis
}

Correspondence Wolf-Rainer Abraham wab@gbf.de

\author{
Andréia B. Estrela and Wolf-Rainer Abraham \\ Helmholtz Center for Infection Research, Chemical Microbiology, Inhoffenstrasse 7, 38124 \\ Braunschweig, Germany
}

The genus Brevundimonas was proposed by Segers et al. (1994) to harbour strains previously assigned to Pseudomonas diminuta and Pseudomonas vesicularis. At that time, Brevundimonas included only species that form short rods that are motile by means of one polar flagellum with a short wavelength. This changed when caulobacteria from a broad range of freshwater, brackish water, marine and soil habitats were studied using a polyphasic approach (Anast \& Smit, 1988; MacRae \& Smit, 1991; Segers et al., 1994). The descriptions of the genera Caulobacter and Brevundimonas were emended and a number of Caulobacter species were transferred to the genus Brevundimonas (Abraham et al., 1999). Today, Brevundimonas species are differentiated from Caulobacter mainly by the lack of loop 46 in the V8 region of the 16S rRNA gene (Abraham et al., 2008), the presence of $\mathrm{C}_{12: 0} 3-\mathrm{OH}$, the glycophospholipid composition and higher salt tolerances. We report here on a novel species within the genus Brevundimonas that was isolated from blood of a patient with endocarditis and preliminarily identified as belonging to Brevundimonas diminuta (Segers et al., 1994).

The reference strains for this study were obtained from the ATCC, DSMZ and LMG culture collections. The strains were grown in the freshwater Caulobacter medium PYEM [per litre MQ-water (Biocel A 10; Millipore): 2 g peptone,

Abbreviation: DGL, 1,2-di-O-acyl-3-O-[ $\beta$-D-glucopyranosyl-( $1 \rightarrow 4)-\alpha$-Dglucopyranuronosyl]glycerol.

The GenBank/EMBL/DDBJ accession number for the 16S rRNA gene sequence of strain LMG $2337^{\top}$ is AJ227779.
$2 \mathrm{~g}$ yeast extract, $0.5 \mathrm{~g} \mathrm{NH}_{4} \mathrm{Cl}$. After autoclaving and cooling, $5 \mathrm{ml}$ filter-sterilized $0.2 \mathrm{mg}$ riboflavin $\mathrm{ml}^{-1}, 2 \mathrm{ml}$ $50 \%$ glucose, $1 \mathrm{ml} 20 \% \mathrm{MgSO}_{4}$ and $1 \mathrm{ml} 10 \% \mathrm{CaCl}_{2}$ (all sterilized) were added. The strains were grown in 21 flasks at $30{ }^{\circ} \mathrm{C}$ with shaking at 100 r.p.m. and biomass was harvested in the late exponential phase after $72 \mathrm{~h}$.

For the determination of DNA base composition, genomic DNA was isolated from two loopfuls of bacterial cells using the DNeasy Blood and Tissue kit for purification of total DNA (Qiagen) with the addition of RNase A (Sigma), according to the manufacturers' instructions. DNA was enzymically digested as described by Gehrke et al. (1984) and the mean $\mathrm{G}+\mathrm{C}$ content was determined by HPLC (Tamaoka \& Komagata, 1984). Calculations were performed according to Mesbah et al. (1989), with nonmethylated lambda phage DNA (Sigma) as the standard. The $\mathrm{G}+\mathrm{C}$ content of strain LMG $2337^{\mathrm{T}}$ was $66.3 \pm$ $0.1 \mathrm{~mol} \%$, which is in the range of values already reported for species of the genus Brevundimonas (Segers et al., 1994; Vancanneyt et al., 2005; Yoon et al., 2006).

The phylogenetic position of strain LMG $2337^{\mathrm{T}}$ was determined by analysis of the $16 \mathrm{~S}$ rRNA gene sequence (Abraham et al., 1999) using CLUSTAL W (Thompson et al., 1997). An alignment of sequences from the EMBL database (Kanz et al., 2005) was used to construct a maximumparsimony tree (Fig. 1) with MEGA version 3.1 (Kumar et al., 2004) and Hirschia baltica DSM $5838^{\mathrm{T}}$ as an outgroup. The $16 \mathrm{~S}$ rRNA gene sequence from strain LMG 


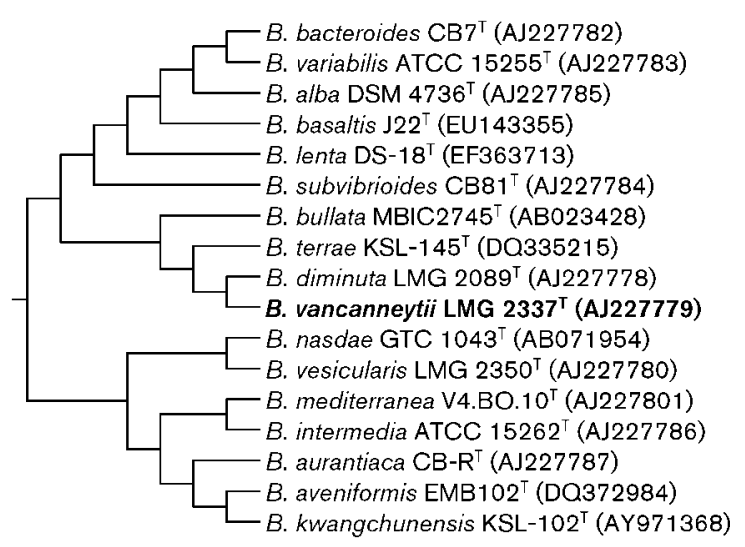

Fig. 1. Maximum-parsimony dendrogram of the phylogenetic relationships between strain LMG $2337^{\top}$ and strains of the genus Brevundimonas, based on a distance-matrix analysis of $16 \mathrm{~S}$ rRNA gene sequences. The sequence of Hirschia baltica DSM $5838^{\top}$ (GenBank accession no. AJ421782) was used as an outgroup (not shown).
$2337^{\mathrm{T}}$ lacked loop 46 in the V8 region, which is characteristic for Brevundimonas species, and had the highest similarities with $B$. diminuta LMG $2089^{\mathrm{T}}(98.3 \%)$ and Brevundimonas terrae KSL- $145^{\mathrm{T}}$ (97.5\%).

To determine whether strain LMG $2337^{\mathrm{T}}$ belonged to the species $B$. diminuta or $B$. terrae or whether it represented a novel species, DNA-DNA hybridizations between strain LMG $2337^{\mathrm{T}}$ and B. diminuta LMG $2089^{\mathrm{T}}$ and B. terrae DSM $17329^{\mathrm{T}}$ were performed. DNA was isolated using a French pressure cell and purified by chromatography on hydroxyapatite as described by Cashion et al. (1977). DNA-DNA hybridization was carried out twice as described by De Ley et al. (1970) using the modification described by Huß et al. (1983) in a Cary 100 Bio UV/Vis spectrophotometer equipped with a Peltier-thermostatted $6 \times 6$ multicell changer and a temperature controller with an in situ temperature probe. The DNA-DNA relatedness between strain LMG $2337^{\mathrm{T}}$ and B. diminuta LMG $2089^{\mathrm{T}}$ and B. terrae DSM $17329^{\mathrm{T}}$ was 62 and $16 \%$, respectively. It has been shown that DNA-DNA relatedness between two strains of $70 \%$ or more qualifies them as members of the same species (Wayne et al., 1987). Hence, the results indicated that strain LMG $2337^{\mathrm{T}}$ indeed belonged to a novel species.

Table 1. Fatty acid contents of whole-cell hydrolysates of strain LMG $2337^{\top}$ and some type strains of the genus Brevundimonas

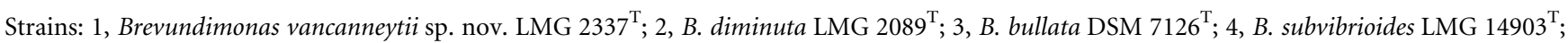
5, B. alba ATCC $15265^{\mathrm{T}}$; 6, B. variabilis ATCC $15255^{\mathrm{T}} ; 7$, B. bacteroides LMG $15096^{\mathrm{T}} ; 8$, B. aurantiaca ATCC $15266^{\mathrm{T}} ; 9$, B. intermedia ATCC $15262^{\mathrm{T}}$; 10 , B. vesicularis LMG $2350^{\mathrm{T}}$. Values are percentages of total fatty acids; data were obtained in this study. ECL, Equivalent chain-length; tr, trace $(<1.0 \%) ;-$, not detected.

\begin{tabular}{|c|c|c|c|c|c|c|c|c|c|c|}
\hline Fatty acid & 1 & 2 & 3 & 4 & 5 & 6 & 7 & 8 & 9 & 10 \\
\hline $\mathrm{C}_{12: 0} 3-\mathrm{OH}$ & 1.8 & 1.5 & 1.3 & 2.8 & 1.1 & 2.3 & 2.3 & 2.3 & 1.7 & 1.9 \\
\hline $\mathrm{C}_{12: 1} 3-\mathrm{OH}$ & - & $\operatorname{tr}$ & $\operatorname{tr}$ & - & $\operatorname{tr}$ & - & - & $\operatorname{tr}$ & - & - \\
\hline $\mathrm{C}_{15: 0}$ & 2.5 & 7.6 & 5.1 & 1.5 & 5.4 & 5.4 & $\operatorname{tr}$ & 3 & 2.8 & 4 \\
\hline ECL 15.275 & - & - & - & - & 2 & - & - & - & - & - \\
\hline $\mathrm{C}_{16: 0}$ & 20.8 & 10.1 & 18.9 & 15.9 & 16.8 & 13.5 & 12.8 & 21.3 & 24.3 & 20.7 \\
\hline $\mathrm{C}_{16: 1} \omega 9 c$ & - & - & - & - & 2.7 & - & - & - & - & - \\
\hline $\mathrm{C}_{17: 0}$ & 1.0 & 8.5 & 1.6 & $\operatorname{tr}$ & 2.5 & 2.2 & $\operatorname{tr}$ & 1.7 & 1.6 & 2.4 \\
\hline $\mathrm{C}_{17: 1} \omega 6 c$ & $\operatorname{tr}$ & 6.2 & 1.5 & $\operatorname{tr}$ & 1.5 & 2.5 & $\operatorname{tr}$ & 1 & 1.1 & 1.4 \\
\hline $\mathrm{C}_{17: 1} \omega 8 c$ & 1.6 & 10.8 & 3.3 & 1.8 & 7.7 & 5.7 & 1.4 & 1.6 & 2 & 2.6 \\
\hline ECL 17.897† & 1.0 & 1.1 & 1.1 & $\operatorname{tr}$ & 1.4 & $\operatorname{tr}$ & $\operatorname{tr}$ & 1.3 & $\operatorname{tr}$ & 1.1 \\
\hline $\mathrm{C}_{18: 0}$ & - & $\operatorname{tr}$ & $\operatorname{tr}$ & 1.4 & $\operatorname{tr}$ & $\operatorname{tr}$ & $\operatorname{tr}$ & $\operatorname{tr}$ & $\operatorname{tr}$ & $\operatorname{tr}$ \\
\hline $\mathrm{C}_{19: 0}$ cyclo $\omega 8 \mathrm{c}$ & 7.4 & 6.2 & 1.1 & - & 2.4 & - & - & - & - & - \\
\hline $\mathrm{C}_{20: 2} \omega 6,9 c$ & - & - & - & 1.6 & - & - & - & - & - & - \\
\hline
\end{tabular}

*Summed features represent groups of two or three fatty acids that cannot be separated by the Microbial Identification System. Summed feature 4 consisted of one or more of iso- $\mathrm{C}_{15: 0} 2-\mathrm{OH}, \mathrm{C}_{16: 1} \omega 7 c$ and $\mathrm{C}_{16: 1} \omega 7 t$. Summed feature 7 consisted of one or more of $\mathrm{C}_{18: 1} \omega 7 c, \mathrm{C}_{18: 1} \omega 9 t$ and $\mathrm{C}_{18: 1} \omega 12 t$.

$\dagger 11$-Methyl-12-trans-octadecanoic acid has ECL 18.080. 
For whole-cell fatty acid analysis, cells were grown at $30{ }^{\circ} \mathrm{C}$ for $48 \mathrm{~h}$ on PYEM agar plates ( $1.5 \%$ agar). Cells were saponified $\left(15 \%, \mathrm{w} / \mathrm{v}, \mathrm{NaOH}\right.$ at $100{ }^{\circ} \mathrm{C}$ for $\left.30 \mathrm{~min}\right)$, methylated to fatty acid methyl esters (methanolic $\mathrm{HCl}$ at $80{ }^{\circ} \mathrm{C}$ for $10 \mathrm{~min}$ ) and extracted (hexane/methyl tert-butyl ether, $1: 1, \mathrm{v} / \mathrm{v}$ ) as described in detail by Osterhout et al. (1991). Fatty acid methyl esters were analysed on a gas chromatograph equipped with a fused-silica capillary column $(25 \mathrm{~m} \times 0.2 \mathrm{~mm})$ with cross-linked $5 \%$ phenyl methyl silicone (film thickness $0.33 \mu \mathrm{m}$; HP Ultra 2) using the protocol of Osterhout et al. (1991). For all strains, the main fatty acids were summed feature 7 (one or more of $\mathrm{C}_{18: 1} \omega 7 c, \mathrm{C}_{18: 1} \omega 9 t$ and $\left.\mathrm{C}_{18: 1} \omega 12 t\right)$ and $\mathrm{C}_{16: 0}$ and the main hydroxy fatty acid was $\mathrm{C}_{12: 0} 3-\mathrm{OH}$, all of which are characteristic of the genus Brevundimonas (Table 1).

Polar lipid analysis with fast atom bombardment mass spectrometry was performed in the negative mode on the first of two mass spectrometers of a tandem high-resolution instrument in an $\mathrm{E}_{1} \mathrm{~B}_{1} \mathrm{E}_{2} \mathrm{~B}_{2}$ configuration (JMS-HX/HX110A; JEOL) using conditions described by Abraham et al. (1997). All strains contained phosphatidylglycerol, 1,2-di-O-acyl-3$O$-[ $\beta$-D-glucopyranosyl- $(1 \rightarrow 4)-\alpha$-D-glucopyranuronosyl] glycerol (DGL), lyso-phosphoglucolipid and 3-O-[6'(sn-glycero-3' -phosphoryl)- $\alpha$-D-glucopyranosyl]-sn-glycerol. The almost exclusive occurrence of $\mathrm{C}_{19: 1}$ DGL and the almost exclusive absence of $\mathrm{C}_{18: 1}$ DGL in strain LMG $2337^{\mathrm{T}}$ are remarkable. Furthermore, sulfoquinovosyl diacylglycerol was detected in strain LMG $2337^{\mathrm{T}}$ (Table 2).

For phenotypic characterization, strains were grown at $30{ }^{\circ} \mathrm{C}$ in $20 \mathrm{ml}$ PYEM amended with $0,5,10,20,30,40,60$, 80 or $100 \mathrm{~g} \mathrm{NaCl} \mathrm{l}^{-1}$. The $\mathrm{OD}_{600}$ of each cell suspension was determined at the beginning of the experiment and after 2 days and the difference between the two measurements was used to determine salt tolerance. Strain LMG $2337^{\mathrm{T}}$ grew best with $5-30 \mathrm{~g} \mathrm{NaCl}^{-1}$ and grew slowly with $60 \mathrm{~g} \mathrm{NaCl}^{-1}$ but not with $80 \mathrm{~g} \mathrm{NaCl}^{-1}$.

Table 2. Phospholipids and sulfolipids in strain LMG $2337^{\top}$ and some type strains of the genus Brevundimonas

Strains: 1, B. vancanneytii sp. nov. LMG $2337^{\mathrm{T}} ; 2$, B. diminuta LMG $2089^{\mathrm{T}}$; 3, B. bullata DSM $7126^{\mathrm{T}} ; 4$, B. subvibrioides LMG $14903^{\mathrm{T}}$; 5, B. variabilis ATCC $15255^{\mathrm{T}} ; 6$, B. bacteroides LMG $15096^{\mathrm{T}} ; 7$, B. aurantiaca DSM $4731^{\mathrm{T}} ; 8$, B. intermedia ATCC $15262^{\mathrm{T}} ; 9$, B. vesicularis LMG $2350^{\mathrm{T}}$. All data were obtained in this study. DGL, 1,2-di- $O$-acyl-3-O-[ $\beta$-D-glucopyranosyl-( $1 \rightarrow 4)$ - $\alpha$-D-glucopyranuronosyl]glycerol; LPGL, lyso-phosphoglucolipid; PGL, 3-O-[6'-(sn-glycero-3'-phosphoryl)- $\alpha$-D-glucopyranosyl]-sn-glycerol; PG, phosphatidylglycerol; SQDG, sulfoquinovosyl diacylglycerol.

\begin{tabular}{|c|c|c|c|c|c|c|c|c|c|c|c|c|}
\hline \multirow[t]{2}{*}{ Mass (Da) } & \multirow[t]{2}{*}{ Polar lipid } & \multicolumn{2}{|c|}{$\mathrm{COOH}$} & \multicolumn{9}{|c|}{ Present in strain: } \\
\hline & & $\mathrm{R}_{1}$ & $\mathbf{R}_{2}$ & 1 & 2 & 3 & 4 & 5 & 6 & 7 & 8 & 9 \\
\hline 746 & PG & $\mathrm{C}_{18: 1}$ & $\mathrm{C}_{16: 1}$ & + & + & + & + & + & - & - & - & - \\
\hline 748 & PG & $\mathrm{C}_{18: 1}$ & $\mathrm{C}_{16: 0}$ & + & + & + & + & + & + & + & + & + \\
\hline 750 & PG & $\mathrm{C}_{19: 0}$ & $\mathrm{C}_{15: 0}$ & - & - & - & - & - & - & - & - & + \\
\hline 774 & PG & $\mathrm{C}_{18: 1}$ & $\mathrm{C}_{18: 1}$ & + & + & + & + & + & + & + & + & + \\
\hline 788 & PG & $\mathrm{C}_{19: 1}$ & $\mathrm{C}_{18: 1}$ & + & + & + & - & + & - & - & - & - \\
\hline 820 & SQDG & $\mathrm{C}_{18: 1}$ & $\mathrm{C}_{16: 0}$ & + & - & + & + & + & + & + & + & - \\
\hline 834 & SQDG & $\mathrm{C}_{18: 1}$ & $\mathrm{C}_{17: 0}$ & - & - & + & + & - & - & - & - & - \\
\hline 846 & SQDG & $\mathrm{C}_{18: 1}$ & $\mathrm{C}_{18: 1}$ & - & - & + & + & + & + & + & + & - \\
\hline 972 & DGL & $\mathrm{C}_{19: 1}$ & $\mathrm{C}_{18: 1}$ & + & - & - & - & - & - & - & - & - \\
\hline 986 & DGL & $\mathrm{C}_{19: 1}$ & $\mathrm{C}_{19: 1}$ & + & + & - & - & - & - & + & - & - \\
\hline 1172 & LPGL & & & - & - & + & - & - & - & - & - & - \\
\hline 1174 & LPGL & & & + & - & + & + & - & + & - & - & - \\
\hline 1411 & PGL & & & - & - & + & + & + & + & - & - & - \\
\hline 1413 & PGL & & & + & + & + & + & + & - & + & + & + \\
\hline 1425 & PGL & & & - & - & - & - & - & + & - & + & - \\
\hline 1427 & PGL & & & + & + & + & + & - & - & + & + & + \\
\hline 1439 & PGL & & & + & + & + & + & + & + & + & + & + \\
\hline 1441 & PGL & & & - & - & - & - & - & - & - & - & - \\
\hline 1453 & PGL & & & + & + & + & - & - & + & + & + & + \\
\hline
\end{tabular}


Substrate specificity tests were conducted with API 20NE test strips (bioMérieux) and GN2 MicroPlates (Biolog), according to the manufacturers' instructions, at $30{ }^{\circ} \mathrm{C}$ for $24 \mathrm{~h}$. A test was considered positive if the interface between the sample well and the air was visibly turbid due to bacterial growth (Rüger \& Krambeck, 1994). The results are given in the species description and in Table 3. It should be noted that strain LMG $2337^{\mathrm{T}}$ showed an exceptionally broad substrate usage, which differed sharply from that of the reference strains. Enzyme activity tests were conducted with API ZYM test strips (bioMérieux), according to the manufacturer's instructions. The test for leucine arylamidase activity was weakly positive in strain LMG $2337^{\mathrm{T}}$ but positive in B. diminuta LMG $2089^{\mathrm{T}}$. The characters that discriminate between strain LMG $2337^{\mathrm{T}}$ and its closest phylogenetic neighbours are summarized in Table 3.

Table 3. Characteristics that are useful for distinguishing strain LMG $2337^{\top}$ from closely related type strains of the genus Brevundimonas

Strains: 1 , B. vancanneytii sp. nov. LMG $2337^{\mathrm{T}} ; 2$, B. terrae DSM $17329^{\mathrm{T}} ; 3$, B. diminuta LMG $2089^{\mathrm{T}} ; 4, B$. bullata DSM $7126^{\mathrm{T}}$. All data were obtained in this study unless indicated otherwise. ++ , Strongly positive; + , positive; $(+)$, weakly positive; - , negative.

\begin{tabular}{|c|c|c|c|c|}
\hline Characteristic & 1 & 2 & 3 & 4 \\
\hline \multicolumn{5}{|l|}{ Enzyme activity } \\
\hline Leucine arylamidase & $(+)$ & $(+)$ & + & ++ \\
\hline Valine arylamidase & $(+)$ & $(+)$ & $(+)$ & ++ \\
\hline Acid phosphatase & ++ & $(+)$ & ++ & + \\
\hline Protease & - & + & - & - \\
\hline \multicolumn{5}{|l|}{ Substrate utilization } \\
\hline Arabinose & + & $(+)$ & $(+)$ & $(+)$ \\
\hline D-Galactose & + & - & - & - \\
\hline Gentiobiose & + & - & - & - \\
\hline Glycogen & - & - & + & $(+)$ \\
\hline Glycerol & $(+)$ & - & ++ & - \\
\hline Maltose & $(+)$ & - & - & - \\
\hline D-Mannose & + & - & + & - \\
\hline Adonitol & + & - & - & - \\
\hline Caprate & ++ & $(+)$ & + & - \\
\hline Malate & ++ & $(+)$ & $(+)$ & $(+)$ \\
\hline$\alpha$-Ketobutyric acid & ++ & - & ++ & - \\
\hline$\alpha$-Ketovaleric acid & ++ & - & + & - \\
\hline$\alpha$-Ketoglutaric acid & + & - & - & - \\
\hline Propionic acid & ++ & - & ++ & $(+)$ \\
\hline Malonic acid & $(+)$ & - & + & - \\
\hline Quinic acid & $(+)$ & - & + & - \\
\hline Bromosuccinic acid & ++ & - & + & - \\
\hline Succinic acid monomethyl ester & ++ & - & ++ & - \\
\hline Pyruvic acid methyl ester & ++ & - & ++ & + \\
\hline Citric acid & $(+)$ & - & - & - \\
\hline$p$-Hydroxyphenylacetic acid & + & - & - & - \\
\hline D-Alanine & ++ & - & $(+)$ & - \\
\hline L-Alanyl glycine & ++ & - & ++ & - \\
\hline L-Asparagine & ++ & - & ++ & - \\
\hline L-Aspartic acid & ++ & - & ++ & - \\
\hline L-Histidine & ++ & - & ++ & - \\
\hline L-Serine & ++ & - & + & - \\
\hline L-Threonine & ++ & - & ++ & - \\
\hline Phenylethylamine & - & - & + & - \\
\hline$N$-Acetyl-D-galactosamine & - & - & + & + \\
\hline Alaninamide & ++ & - & ++ & - \\
\hline$\alpha$-Cyclodextrin & - & - & + & - \\
\hline DNA G $+C$ content $(\mathrm{mol} \%)$ & 66.3 & $61.8^{a_{\star}}$ & $65.9^{b}$ & $66.7^{c}$ \\
\hline
\end{tabular}

${ }^{\star}$ Data from: $a$, Yoon et al. (2006); b, Segers et al. (1994); c, Fritz (2000). 
Strain LMG $2337^{\mathrm{T}}$ could be differentiated from all hitherto-described Brevundimonas species. In particular, strain LMG $2337^{\mathrm{T}}$ differed from B. terrae DSM $17329^{\mathrm{T}}$ by having strong acid phosphatase activity and the ability to use $\alpha$-keto-fatty acids and many amino acids, from $B$. diminuta LMG $2089^{\mathrm{T}}$ by having smaller amounts of $\mathrm{C}_{17: 1} \omega 6 c$ and $\mathrm{C}_{17: 1} \omega 8 c$, the ability to use p-hydroxyphenylacetic acid, D-gentiobiose, D-alanine and adonitol and from Brevundimonas bullata DSM $7126^{\mathrm{T}}$ by the ability to use many amino acids. As a consequence, we propose a novel species, Brevundimonas vancanneytii sp. nov.

\section{Description of Brevundimonas vancanneytii sp. nov.}

Brevundimonas vancanneytii (van.can.ney'ti.i. N.L. masc. gen. n. vancanneytii of Vancanneyt, named after Marc Vancanneyt, a microbiologist in Ghent, Belgium, who has contributed to the chemotaxonomy of many genera).

Cells are short rods and motile by one polar flagellum with no prosthecae. Cell division is by fission. Colonies are whitish yellow. Grows on peptone yeast extract medium with $0-60 \mathrm{~g} \mathrm{NaCl} \mathrm{l}^{-1}$ but not with $80 \mathrm{~g} \mathrm{NaCll}^{-1}$. Utilizes $\alpha$ $(+)$-D-glucose, $\beta$ - $(+)$-D-fructose, $(+)$-D-galactose, $(+)$ trehalose, $(+)$-D-mannose, $(+)$-melibiose, sucrose, $(+)$ raffinose, maltose, lactose, D-psicose, $(+)$-gentiobiose, $(+)$-L-arabinose, $\alpha$-L-rhamnose, $\alpha$-L-fucose, $(+)$-turanose, (+)-D-arabitol, glycerol, myo-inositol, D-mannitol, D-sorbitol, adonitol, D-saccharic acid, malic acid, cis-aconitic acid, citric acid, D-glucuronic acid, D-galacturonic acid, Dgluconic acid, $p$-hydroxyphenylacetic acid, $(-)$-quinic acid, 4-aminobutyric acid, DL-lactic acid, succinic acid, capric acid, itaconic acid, pyruvic acid methyl ester, succinic acid monomethyl ester, $\alpha-, \beta$ - and $\gamma$-hydroxybutyric acids, propionic acid, acetic acid, bromosuccinic acid, $\alpha$-ketobutyric acid, $\alpha$-ketoglutaric acid, $\alpha$-ketovaleric acid, formic acid, malonic acid, sebacic acid, D-galactonic acid lactone, D-glucosaminic acid, urocanic acid, succinamic acid, Lpyroglutamic acid, L-aspartic acid, L-glutamic acid, glycyl Lglutamic acid, glycyl L-aspartic acid, L-alanyl glycine, hydroxy-L-proline, L-threonine, L-leucine, L-histidine, Lasparagine, L-proline, D- and L-alanine, D- and L-serine, Lornithine, L-phenylalanine, $N$-acetyl-D-glucosamine, putrescine, 2-aminoethanol, alaninamide, Tweens 40 and 80, methyl D-glucoside, dextrin, glucuronamide, uridine, 2,3butanediol, DL- $\alpha$-glycerol phosphate, glucose 1-phosphate and glucose 6-phosphate. Does not utilize glycogen, inosine, thymidine, aesculin, arginine, urea or tryptophan. Nitrate is not reduced. Produces alkaline and acid phosphatases, esterase (C4), esterase lipase (C8), leucine arylamidase, trypsin, $\alpha$-chymotrypsin, naphthol-AS-BI-phosphohydrolase and oxidase, but not catalase. The polar lipids are $\alpha$-Dglucopyranosyl-, $\alpha$-D-glucuronopyranosyl-, $\beta$-D-glucopyranosyl- $(1 \rightarrow 4)-\alpha$-D-glucopyranuronosyl-, sulfoquinovosyl-, phosphatidyl- and 6-phosphatidyl- $\alpha$-D-glucopyranosyl diacylglycerols. The major fatty acids $(>10 \%)$ are summed feature 7 (one or more of $\mathrm{C}_{18: 1} \omega 7 c, \mathrm{C}_{18: 1} \omega 9 t$ and $\left.\mathrm{C}_{18: 1} \omega 12 t\right)$ and $\mathrm{C}_{16: 0}$. The minor fatty acids are $\mathrm{C}_{19: 0}$ cyclo $\omega 8 c$, summed feature 4 (one or more of iso- $\mathrm{C}_{15: 0} 2-\mathrm{OH}$, $\mathrm{C}_{16: 1} \omega 7 c$ and $\left.\mathrm{C}_{16: 1} \omega 7 t\right), \mathrm{C}_{15: 0}, \mathrm{C}_{12: 0} 3-\mathrm{OH}, \mathrm{C}_{17: 1} \omega 8 c$, $\mathrm{C}_{14: 0}, 11$-methyl $\mathrm{C}_{18: 1} \omega 5 t$ and $\mathrm{C}_{17: 0}$. The $\mathrm{G}+\mathrm{C}$ content of the type strain is $66.3 \mathrm{~mol} \%$.

The type strain is LMG $2337^{\mathrm{T}}$ (=CCUG $1797^{\mathrm{T}}=$ ATCC $\left.14736^{\mathrm{T}}\right)$, isolated from blood of a patient with endocarditis.

\section{Acknowledgements}

We thank Marc Vancanneyt for his contribution to the cellular fatty acid analyses. We are indebted to Dagmar Wenderoth and Peter Wolff for their excellent technical assistance. This work was supported by grants of the European Union within the T-project 'High Resolution Automated Microbial Identification and Application to Biotechnologically Relevant Ecosystems' and the German Federal Ministry for Science, Education and Research (projects no. 0319433C and 01 KI 07 96).

\section{References}

Abraham, W.-R., Meyer, H., Lindholst, S., Vancanneyt, M. \& Smit, J. (1997). Phospho- and sulfolipids as biomarkers of Caulobacter sensu lato, Brevundimonas and Hyphomonas. Syst Appl Microbiol 20, 522539.

Abraham, W.-R., Strömpl, C., Meyer, H., Lindholst, S., Moore, E. R. B., Christ, R., Vancanneyt, M., Tindall, B. J., Bennasar, A. \& other authors (1999). Phylogeny and polyphasic taxonomy of Caulobacter species. Proposal of Maricaulis gen. nov. with Maricaulis maris (Poindexter) comb. nov. as the type species, and emended description of the genera Brevundimonas and Caulobacter. Int J Syst Bacteriol 49, 1053-1073.

Abraham, W.-R., Macedo, A. J., Lünsdorf, H., Fischer, R., Pawelczyk, S., Smit, J. \& Vancanneyt, M. (2008). Phylogeny by a polyphasic approach of the order Caulobacterales, proposal of Caulobacter mirabilis sp. nov., Phenylobacterium haemophilum sp. nov. and Phenylobacterium conjunctum sp. nov., and emendation of the genus Phenylobacterium. Int $J$ Syst Evol Microbiol 58, 1939-1949.

Anast, N. \& Smit, J. (1988). Isolation and characterization of marine caulobacters and assessment of their potential for generic experimentation. Appl Environ Microbiol 54, 809-817.

Cashion, P., Holder-Franklin, M. A., McCully, J. \& Franklin, M. (1977). A rapid method for the base ratio determination of bacterial DNA. Anal Biochem 81, 461-466.

De Ley, J., Cattoir, H. \& Reynaerts, A. (1970). The quantitative measurement of DNA hybridization from renaturation rates. Eur $J$ Biochem 12, 133-142.

Fritz, I. (2000). Das Bakterioplankton im Westlichen Mittelmeer. $\mathrm{PhD}$ thesis, Technical University Braunschweig, Braunschweig, Germany. http://www.biblio.tu-bs.de/ediss/data/20000811a/20000811a.html (in German with English abstract).

Gehrke, C. W., McCune, R. A., Gama-Sosa, M. A., Ehrlich, M. \& Kuo, K. C. (1984). Quantitative reversed-phase high-performance liquid chromatography of major and modified nucleosides in DNA. J Chromatogr A 301, 199-219.

Huß, V. A. R., Festl, H. \& Schleifer, K. H. (1983). Studies on the spectrophotometric determination of DNA hybridization from renaturation rates. Syst Appl Microbiol 4, 184-192.

Kanz, C., Aldebert, P., Althorpe, N., Baker, W., Baldwin, A., Bates, K., Browne, P., van den Broek, A., Castro, M. \& other authors (2005). The EMBL nucleotide sequence database. Nucleic Acids Res 33, D29D33. 
Kumar, S., Tamura, K. \& Nei, M. (2004). MEGA3: integrated software for molecular evolutionary genetics analysis and sequence alignment. Brief Bioinform 5, 150-163.

MacRae, J. D. \& Smit, J. (1991). Characterization of caulobacters isolated from wastewater treatment systems. Appl Environ Microbiol 57, 751-758.

Mesbah, M., Premachandran, U. \& Whitman, W. B. (1989). Precise measurement of the $\mathrm{G}+\mathrm{C}$ content of deoxyribonucleic acid by highperformance liquid chromatography. Int J Syst Bacteriol 39, 159-167.

Osterhout, G. J., Shull, V. H. \& Dick, J. D. (1991). Identification of clinical isolates of gram-negative nonfermentative bacteria by an automated cellular fatty acid identification system. J Clin Microbiol 29, 1822-1830.

Rüger, H.-J. \& Krambeck, H.-J. (1994). Evaluation of the BIOLOG substrate metabolism system for classification of marine bacteria. Syst Appl Microbiol 17, 281-288.

Segers, P., Vancanneyt, M., Pot, B., Torck, U., Hoste, B., Dewettinck, D., Falsen, E., Kersters, K. \& De Vos, P. (1994). Classification of Pseudomonas diminuta Leifson and Hugh 1954 and Pseudomonas vesicularis Büsing, Döll, and Freytag 1953 in Brevundimonas gen. nov. as Brevundimonas diminuta comb. nov. and Brevundimonas vesicularis comb. nov., respectively. Int J Syst Bacteriol 44, 499-510.
Tamaoka, J. \& Komagata, K. (1984). Determination of DNA base composition by reversed-phase high-performance liquid chromatography. FEMS Microbiol Lett 25, 125-128.

Thompson, J. D., Gibson, T. J., Plewniak, F., Jeanmougin, F. \& Higgins, D. G. (1997). The CLUSTAL_X windows interface: flexible strategies for multiple sequence alignment aided by quality analysis tools. Nucleic Acids Res 25, 4876-4882.

Vancanneyt, M., Segers, P., Abraham, W.-R. \& De Vos, P. (2005). Genus III. Brevundimonas Segers, Vancanneyt, Pot, Torck, Hoste, Dewettinck, Falsen, Kersters and De Vos 1994, 507 ${ }^{\mathrm{VP}}$ emend. Abraham, Strömpl, Meyer, Lindholst, Moore, Christ, Vancanneyt, Tindall, Bennasar, Smit and Tesar 1999, 1070. In Bergey's Manual of Systematic Bacteriology, 2nd edn, vol. 2C, pp. 308-315. Edited by D. J. Brenner, N. R. Krieg, J. T. Staley \& G. M. Garrity. New York: Springer.

Wayne, L. G., Brenner, D. J., Colwell, R. R., Grimont, P. A. D., Kandler, O., Krichevsky, M. I., Moore, L. H., Moore, W. E. C., Murray, R. G. E. \& other authors (1987). International Committee on Systematic Bacteriology. Report of the ad hoc committee on reconciliation of approaches to bacterial systematics. Int J Syst Bacteriol 37, 463-464.

Yoon, J.-H., Kang, S.-J., Lee, J.-S. \& Oh, T.-K. (2006). Brevundimonas terrae sp. nov., isolated from an alkaline soil in Korea. Int J Syst Evol Microbiol 56, 2915-2919. 